\title{
Ni víctimas, ni criminales: Trabajadoras sexuales. Una crítica feminista a las políticas contra la trata de personas y la prostitución
}

\author{
Nataly Escribano Velásquez \\ Universidad de Chile
}

g Marisa S. Tarantino, Ni víctimas ni criminales: Trabajadoras sexuales. Una crítica feminista a las políticas contra la trata de personas y la prostitución, Ciudad de México, Fondo de Cultura Económica, 2021, 264 páginas.

En nuestra concepción occidental, la prostitución ha sido un tema tabú, algo que sabemos que existe, pero de lo que no se habla o, al menos, así lo creía hasta antes de leer Ni víctimas ni criminales: trabajadoras sexuales Una crítica feminista a las políticas contra la trata de personas y la prostitución.

A través de un lenguaje sencillo, Marisa S. Tarantino da cuenta de una investigación que llevó a cabo durante años, interdisciplinaria desde un punto de vista jurídico, sociológico, antropológico y criminológico, con un enfoque histórico y feminista, en formato libro.

El tema central es la situación actual de la política criminal argentina en torno a la prostitución y el estigma generado por la tensa y errónea relación entre ella y la trata de personas. La hipótesis de la autora es que en Argentina, actualmente, aumentó la criminalización de las trabajadoras sexuales como consecuencia de las políticas antitrata, reflejada principalmente en la legislación de tipo punitivista. A través de los cinco capítulos que integran esta publicación, la autora vislumbra los orígenes históricos de este problema, de la regulación $-\mathrm{o}$, más bien, no regulación - de la prostitución en el mundo occidental y de cómo influyeron los debates feministas del siglo XX y las políticas a nivel internacional en la configuración actual de las políticas criminales, particularmente en las argentinas.

El libro aborda cronológicamente los inicios de la regulación de la prostitución en la época victoriana de fines del siglo XIX y principios del siglo XX, cuando se origina el problema de la trata sexual. Además, se explica cuál era el contexto político y social 
en desarrollo y cómo se regulaba la prostitución en la época, cuya primera reglamentación fue de tipo higienista, asociando la prostitución a un foco de enfermedades en las urbes. Esto mismo influyó en la percepción de la época con respecto a las prostitutas, vistas como seres inmorales y fuera de los límites del contrato social, además de la consiguiente persecución policial y desprotección. Un elemento importante a considerar por parte de la autora fue el fenómeno de la migración, que acompañó al trabajo sexual, ya que este se veía como una oportunidad de salir de la pobreza.

En este contexto surgieron los movimientos abolicionistas, que equipararon la prostitución a la esclavitud, la cual atenta contra la dignidad humana, y situaron a las trabajadoras sexuales como víctimas. Estos movimientos, a criterio de la autora, encontraron una alianza con los sectores moralmente conservadores, ya que perseguían un objetivo en común: la erradicación de la prostitución y la consecución de la liberación de las prostitutas.

Así, Marisa S. Tarantino también profundizó en las figuras que representaron el abolicionismo de la época: mujeres blancas de clase acomodada que eliminaron factores de la discusión, como la clase, la raza y la nacionalidad, reduciendo el problema a la prostitución de las mujeres migrantes, lo que gatilló el establecimiento del término trata de blancas, con profundos tintes racistas, ya que la posibilidad de que una mujer blanca se dedicara voluntariamente al trabajo sexual era inconcebible, no así una mujer nativa. Este concepto se desarrolló a nivel local y se profundizó gracias a la narrativa criolla. Así, llegó hasta los primeros instrumentos internacionales, que comenzaron a legislar ya no con respecto a la trata de blancas, sino a la trata de personas.

En el segundo capítulo, la autora continúa con la línea cronológica, aunque, esta vez, centrando el relato en la teorización de los primeros debates feministas, en los que ocurrieron los primeros cruces entre el feminismo abolicionista y su vertiente más radical/cultural y el feminismo prosexo. El debate giró en torno a la sexualidad, donde el feminismo cultural asociaba la sexualidad con el peligro sexual, y el feminismo prosexo, que asociaba la sexualidad al placer. En esta misma contraposición, también se discutió en torno a la prostitución. Así, para el feminismo cultural era sinónimo de dominación masculina y nunca podría ser considerado como un trabajo.

¿Pero qué pasaba con las trabajadoras sexuales de la época? Estuvieron ausentes de los debates hasta principio de la década de los setenta, momento en el que surgieron los primeros sindicatos de trabajadoras sexuales, los cuales se alinearon con el feminismo prosexo y dieron inicio al camino de la reivindicación de la prostitución como trabajo.

La década de los noventa trajo consigo el cambio de paradigma desde la opresión a la violencia de género, momento en que se empezó a visibilizar la violencia tanto física como económica y sexual en la esfera pública. Esto, sumado a la agenda internacional de los distintos tratados para la promoción y la defensa de los derechos 
humanos, en particular los de las mujeres, detonó que la prostitución volviera a estar en la palestra de los debates, y, de la mano de las políticas estadounidenses que condenaban la trata de personas (como la utilización de los trafficking in persons report o los compromisos de la Anti Prostitution Pledge), demarcaron un camino bastante definido para que, en el escenario argentino, se adoptaran leyes que reflejaran esta campaña antitrata.

En el cuarto capítulo se aborda el escenario argentino, en particular en el proceso de reconfiguración de la política criminal en torno a la Ley 26.364 de 2008, la cual establece nuevas figuras penales para la trata de personas, agudizando el corte punitivista que ya tenían las políticas públicas en ese entonces y también el desconcierto del mundo jurídico, donde no tardaron en aparecer los problemas de esta nueva regulación en términos de interpretación, tanto desde la vereda de la teoría del delito como desde la conceptualización de términos, como el consentimiento, la vulnerabilidad o la explotación.

Hacia el final de la obra, los capítulos anteriores se entrelazan y le dan sustento al quinto y último capítulo, el cual hace un análisis cuantitativo y cualitativo del impacto que tuvo la política criminal antitrata sobre el trabajo sexual argentino, que, en definitiva, a ojos de la autora, conllevó a aumentar aún más la precarización del trabajo sexual, ya que, lisa y llanamente, se prohibieron tanto los avisos publicitarios en torno a la prostitución como los espacios públicos en los se ofrecían los trabajos sexuales. Todo esto favoreció el contexto de la clandestinidad y la persecución de las mujeres por desempeñar su trabajo en estas condiciones. La norma que, en definitiva, buscó proteger y amparar los derechos de mujeres y niñas, dejó a algunas en un estado de total desamparo.

A pesar de estar enfocada en la situación argentina, tanto a nivel histórico-político como legislativo, esta obra nos ayuda a comprender, en términos transversales, la situación latinoamericana en torno a la prostitución, constituyendo un aporte a la reflexión y planteando una problemática histórica, dándole un nuevo giro y nuevos puntos de vista en pos de la solución a un problema que actualmente afecta a miles de mujeres a lo largo del territorio.

Además de la rica y abundante bibliografía, el texto es enriquecido a través del relato y del testimonio de importantes actoras de los sindicatos de trabajadoras sexuales en Argentina, como también de cifras estadísticas utilizadas por la autora para socializar la situación actual vivida por las voces históricamente acalladas, las de las trabajadoras sexuales.

\section{Sobre la autora}

Nataly Escribano Velásquez es licenciada en Ciencias Jurídicas y Sociales de la Universidad de Chile. Actualmente, se desempeña como ayudante ad honorem 
en el Centro de Derechos Humanos de la Facultad de Derecho de la misma universidad. Su correo electrónico es nataly.escribano@ug.uchile.cl. (D) https://orcid. org/0000-0003-3911-1202. 